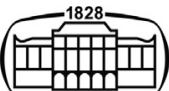

AKADÉMIAI KIADÓ

Journal of Psychedelic Studies

$5(2021) 1,55$

DOl:

$10.1556 / 2054.2021 .10000$

(c) 2021 The Author(s)

\section{ERRATUM}

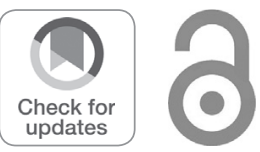

\title{
ERRATUM: MAKING PSYCHEDELICS INTO MEDICINES: THE POLITICS AND \\ PARADOXES OF MEDICALIZATION
}

\section{TEHSEEN NOORANI*}

Department of Anthropology, Durham University, Durham, UK

ERRATUM: Journal of Psychedelic Studies 4 (1) (2020) 34-39

DOI: $10.1556 / 2054.2019 .018$

On p. 37 of the article, 'ketamine' was accidentally included in a list:

"Not anticipated by the US Controlled Substances Act, such bifurcations have been created on an ad hoc basis, for cannabinoids, gamma hydroxybutyrate, and ketamine (Ismail Lourido Ali, personal communication, June 19, 2019), offering the FDA a legal mechanism by which to create markets for tightly regulating licit use while avoiding concerns with or backlash from rescheduling substances in toto."

This paragraph listing should not include 'ketamine'. Thus, the paragraph should read as follows:

"Not anticipated by the US Controlled Substances Act, such bifurcations have been created on an ad hoc basis, for cannabinoids and gamma hydroxybutyrate (Ismail Lourido Ali, personal communication, June 19,2019), offering the FDA a legal mechanism by which to create markets for tightly regulating licit use while avoiding concerns with or backlash from rescheduling substances in toto."

Editorial

Open Access. This is an open-access article distributed under the terms of the Creative Commons Attribution-NonCommercial 4.0 International License (https://creativecommons.org/licenses/by-nc/4.0/), which permits unrestricted use, distribution, and reproduction in any medium for non-commercial purposes, provided the original author and source are credited, a link to the CC License is provided, and changes - if any - are indicated. 